\title{
Clinical Reasoning: A 79-Year-Old Woman With Subacute Bilateral Visual Loss
}

Simone Rossi, MD, Giulia Amore, MD, Umberto Pensato, MD, Roberto D’Angelo, MD, Rita Rinaldi, MD, Maria Guarino, MD, and Pietro Cortelli, MD, PhD

Neurology ${ }^{\circledR}$ 2021;97:e1159-e1165. doi:10.1212/WNL.0000000000012235

\section{Section 1}

A 79-year-old woman presented with a 10-day history of rapidly progressive bilateral visual loss with more prominent involvement of the right eye. Her medical history was significant for an infiltrative breast carcinoma treated with mastectomy and chemotherapy (cyclophosphamide, doxorubicin, and paclitaxel) 1 year before, complicated by bilateral foot paresthesias and decreased sensation. The patient achieved complete remission from cancer and maintained regular oncologic follow-up. On admission, vision was limited to hand motion in the right eye and markedly reduced in the left eye (20/50), so that she was unable to read. Color vision was untestable in the right eye and remained intact in the left eye. A right relative afferent pupillary defect (RAPD) was observed. Intraocular pressure was normal, whereas funduscopic evaluation revealed bilateral optic disc swelling. Extraocular movements were full and not painful and other cranial nerves were intact. The rest of the neurologic examination was unrevealing, apart from signs of a distal symmetric sensory polyneuropathy.

\section{Questions for Consideration:}

1. Where would you localize the lesion responsible for vision loss along the visual pathway?

2. What are the possible etiologies, and which etiology is the most important to exclude in the acute setting?

\author{
Correspondence \\ Dr. Rossi \\ simonerossi.91@gmail.com
}

GO TO SECTION 2 


\section{Section 2}

Vision loss represents a diagnostic challenge because several different structures within the visual pathways may be involved. The first question to address is whether the visual loss is monocular or binocular. Monocular vision loss is usually due to homolateral lesions within the eye or along the optic nerve; binocular vision loss can result from damage to both eyes, optic nerves, chiasm, or retrochiasmal visual pathways. Lesions at the level of, or behind, the chiasm produce bilateral visual field defects with respect to the vertical meridian. Thus, if the vision loss is of intracranial origin, a specific pattern of visual field defects may be observed (i.e., right homonymous hemianopsia for left optic tract lesions). ${ }^{1}$ Our patient presented with subacute and severe binocular vision loss, diffuse visual field defects, bilateral swollen optic discs, and a right RAPD. Overall, these clinical features point towards bilateral, although asymmetric, optic nerve involvement. Optical coherence tomography confirmed bilateral optic disc edema and a visual evoked potential test revealed bilateral prolonged latency and reduced amplitude of the cortical P100 response.

Optic neuropathies can be classified according to underlying etiology in the following groups (table $)^{2}$ :

- Papilledema results from increased intracranial pressure secondary to space-occupying lesions, obstructive hydrocephalus, venous sinus obstruction, or idiopathic intracranial hypertension.

- Inflammatory optic neuritis occurs in demyelinating disorders (e.g., multiple sclerosis, neuromyelitis optica, or anti-myelin oligodendrocyte glycoprotein [MOG] syndromes) or in association with various infectious (e.g., cat-scratch disease or syphilis) or noninfectious diseases (e.g., sarcoidosis).

- Ischemic optic neuropathy, classified into nonarteritic (NAION) and arteritic forms, the latter of which is mostly associated with giant cell arteritis (GCA).

Table Clinical and Demographic Characteristics of Optic Neuropathies

\begin{tabular}{|c|c|c|c|c|c|c|c|}
\hline & Papilledema & Optic neuritis & NAION & AION & $\begin{array}{l}\text { Compressive or } \\
\text { infiltrative } \\
\text { neuropathy }\end{array}$ & $\begin{array}{l}\text { Toxic/ } \\
\text { nutritional } \\
\text { neuropathy }\end{array}$ & $\begin{array}{l}\text { Hereditary } \\
\text { neuropathy } \\
\text { (e.g., LHON) }\end{array}$ \\
\hline Age, y & Any & $<40$ & $>50$ & $>50$ & $\begin{array}{l}\text { - Childhood for } \\
\text { glioma } \\
\text { • } 30-50 \text { for } \\
\text { meningioma } \\
\text { - Variable based } \\
\text { on tumor type for } \\
\text { LC }\end{array}$ & Any age & $<40$ \\
\hline Sex & $\begin{array}{l}\mathrm{F}>\mathrm{M} \\
\text { (pseudotumor } \\
\text { cerebri) }\end{array}$ & $\mathrm{F}>\mathrm{M}$ & $F>M$ & $F>>M$ & No preference & No preference & $M>>F$ \\
\hline Laterality & Bilateral & Usually unilateral & Unilateral & Usually unilateral & Usually unilateral & Bilateral & Bilateral \\
\hline $\begin{array}{l}\text { Visual loss } \\
\text { progression }\end{array}$ & Slowly progressive & Rapidly progressive & Acute & Acute/subacute & Variable & $\begin{array}{l}\text { Slowly } \\
\text { progressive } \\
\text { (could be acute in } \\
\text { toxic causes) }\end{array}$ & $\begin{array}{l}\text { Usually slowly } \\
\text { progressive } \\
\text { (could be } \\
\text { subacute in } \\
\text { LHON) }\end{array}$ \\
\hline $\begin{array}{l}\text { Orbital } \\
\text { pain }\end{array}$ & Absent & Usually present & Infrequent & $\begin{array}{l}\text { Usually absent; } \\
\text { could be present in } \\
10 \% \text { of patients }\end{array}$ & Usually absent & Absent & Absent \\
\hline Color vision & Preserved until late & Abnormal & $\begin{array}{l}\text { Variably } \\
\text { spared }\end{array}$ & Variably spared & Abnormal & Abnormal & Abnormal \\
\hline Visual field & $\begin{array}{l}\text { Peripheral } \\
\text { constriction }\end{array}$ & Central defect & $\begin{array}{l}\text { Inferior } \\
\text { altitudinal } \\
\text { defect }\end{array}$ & Variable & Variable & Central defect & Central defect \\
\hline $\begin{array}{l}\text { Optic disc } \\
\text { in the acute } \\
\text { stage }\end{array}$ & Disc edema & $\begin{array}{l}\text { Normal ( } 2 / 3 \text { of cases) or } \\
\text { edema ( } 1 / 3 \text { of cases) }\end{array}$ & $\begin{array}{l}\text { Disc edema; } \\
\text { splinter } \\
\text { hemorrhages }\end{array}$ & $\begin{array}{l}\text { Disc edema; } \\
\text { cotton-wool spots } \\
\text { may be present }\end{array}$ & Variable & Normal & $\begin{array}{l}\text { "Pseudo-edema" } \\
\text { with peripapillary } \\
\text { telangiectasias }\end{array}$ \\
\hline $\begin{array}{l}\text { Associated } \\
\text { symptoms }\end{array}$ & $\begin{array}{l}\text { Headache, tinnitus, } \\
\text { diplopia } \\
\text { (oculomotor nerve } \\
\text { palsies) }\end{array}$ & $\begin{array}{l}\text { Variable, depending on } \\
\text { the presence of other } \\
\text { inflammatory lesions }\end{array}$ & Absent & $\begin{array}{l}\text { Headache, jaw } \\
\text { claudication, } \\
\text { constitutional } \\
\text { symptoms }\end{array}$ & $\begin{array}{l}\text { Other cranial } \\
\text { nerve or } \\
\text { radicular } \\
\text { involvement (LC) }\end{array}$ & $\begin{array}{l}\text { Peripheral } \\
\text { neuropathy }\end{array}$ & Absent in LHON \\
\hline
\end{tabular}

Abbreviations: AION = anterior ischemic optic neuropathy; LC = leptomeningeal carcinomatosis; LHON = Leber hereditary optic neuropathy; NAION = nonarteritic anterior ischemic optic neuropathy.

Modified from Biousse and Newman (2016). 
- Compressive or infiltrative optic neuropathy secondary to locally expanding lesions or in the setting of a leptomeningeal carcinomatosis.

- Toxic or nutritional optic neuropathy due to several toxic agents (methanol, some antibacterial drugs) or nutritional deficiency $\left(B_{12}\right.$, thiamine, folate).

- Hereditary optic neuropathy.

A high index of suspicion for GCA should be present for all patients over 50 years of age presenting with acute optic neuropathy because prompt institution of high-dose systemic corticosteroid therapy could prevent further visual loss. Accordingly, these patients should undergo laboratory studies including complete blood count, erythrocyte sedimentation rate, and C-reactive protein. GCA-induced blindness is often associated with headache, jaw claudication, and constitutional symptoms. Our patient had unremarkable blood tests and no associated symptoms. However, because visual loss has been described as the only presenting sign in $\mathrm{GCA}^{3}$ and inflammatory markers could be normal in patients with GCA-induced visual loss, ${ }^{4}$ high-dose methylprednisolone $(1 \mathrm{~g} / \mathrm{d})$ therapy was instituted. Meanwhile, we continued the diagnostic workup, looking for potential alternative diagnoses.

\section{Question for Consideration:}

1. Which investigations would you pursue?

GO TO SECTION 3 


\section{Section 3}

An extensive blood examination, including glycated hemoglobin, lipid profile, vitamin $\mathrm{B}_{12}$, and folate, was normal. Autoimmune screening for antinuclear antibodies, p- and c-ANCA, and angiotensin-converting enzyme was negative. Diagnostic testing for syphilis, Bartonella henselae, tuberculosis, and HIV was negative. Anti-aquaporin-4 and anti-MOG antibodies were negative. Because a paraneoplastic optic neuropathy is anecdotally reported in association with CRMP-5 antibodies, ${ }^{5}$ we tested for the presence of serum onconeural antibodies, which also turned out negative. Contrast-enhanced MRI of the head and orbits was unremarkable, with no signs of optic nerve or chiasm pathology, sinus thrombosis, or space-occupying lesions. Lumbar puncture (LP) revealed increased protein level (241 mg/dL), normal glucose level, and increased cell count
(18 leukocytes, 83\% lymphocytes), with an increased CSF/ serum albumin index $(46$, normal values $<7.4)$ and a normal Link index (0.57, normal values 0.33-0.66), suggesting blood-brain barrier (BBB) disruption with no immunoglobulin $\mathrm{G}$ intrathecal synthesis. No oligoclonal bands were detected in CSF or serum. Cytologic and flow cytometry immunophenotyping examinations were negative for neoplastic cells. Cryptococcal serology and herpes simplex virus PCR were negative in the CSF sample.

Meanwhile, no clinical benefit was obtained from corticosteroid therapy and visual acuity deteriorated further, resulting in bilateral blindness.

\section{Question for Consideration:}

1. What is the most likely diagnosis at this point? 


\section{Section 4}

Absent corticosteroid response, along with normal inflammatory markers and the absence of associated constitutional symptoms, was inconsistent with a diagnosis of GCA in our patient. NAION was excluded based on bilateral optic nerve involvement, diffuse visual loss (with no altitudinal pattern), the absence of retinal hemorrhages on funduscopic examination, and the lack of cardiovascular risk factors. A taxane-induced optic neuropathy ${ }^{6}$ was considered; however, the long latency between the discontinuation of paclitaxel and symptom onset made this hypothesis unlikely. Normal laboratory findings excluded nutritional etiologies and the age at onset was not consistent with hereditary causes.

A possible inflammatory optic neuropathy was diagnosed based on CSF lymphocytic pleocytosis and BBB disruption, even though no specific antibodies or neuroradiologic abnormalities were found. Because no response to corticosteroids was observed previously, therapy with IV immunoglobulins was empirically instituted.

One week after our first evaluation (about 17 days after the onset of vision loss), the patient developed subacute bilateral proximal lower limb weakness (ileopsoas, quadriceps, and biceps femoris) with absent deep tendon reflexes in her lower limbs. Electroneurography, performed 1 week after the onset of paraparesis, showed prolonged latency and reduced persistence of tibial $\mathrm{F}$ waves bilaterally, consistent with proximal demyelination.

\section{Questions for Consideration:}

1. How does the development of areflexic paraparesis change the differential diagnosis?

2. Would you perform any further investigations? 


\section{Section 5}

Areflexic paraparesis along with neurophysiologic evidence of proximal demyelination may suggest a polyradiculopathy secondary to spinal meningeal involvement. Bilateral optic neuropathy, even in the absence of other cranial nerve defects, could be the expression of cranial meningeal involvement. Given the strong suspicion for diffuse leptomeningeal involvement, LP was repeated and a relatively high volume (10 $\mathrm{mL}$ ) was submitted for cytologic examination. This time, malignant cells were detected and immunohistochemical staining was consistent with breast carcinoma. The patient was referred to the Oncology Department and treated with systemic chemotherapy with carboplatin and gemcitabine. She developed neutropenic fever and died 1 week after the first infusion.

\section{Discussion}

Leptomeningeal carcinomatosis (LC) is an uncommon and devastating complication of metastatic malignancies, occurring in 5\%-8\% of patients with solid tumors. ${ }^{7}$ Cancers most often associated with leptomeningeal spread are lung cancer, breast cancer, and melanoma. ${ }^{7}$ Clinical presentation of LC is highly pleiomorphic and depends on the location of the affected areas. Headache is the most common symptom and multiple cranial neuropathies occur in more than $50 \%$ of patients, usually involving the vestibulocochlear or oculomotor nerves. ${ }^{8}$ Conversely, bilateral optic neuropathy has been rarely reported and can result from either increased intracranial pressure, related to an increase in CSF viscosity, or direct infiltration of the subarachnoid space around the optic nerves by cancer cells. The latter mechanism was more likely in our patient, as it produces quickly deteriorating visual loss, in contrast with the more subtle vision deficits observed in papilledema.

The diagnosis of LC remains challenging, with no test sufficiently sensitive to rule out meningeal involvement. Contrast-enhanced MRI may reveal diffuse leptomeningeal enhancement in brain or vertebral canal, subependymal enhancement, nodules of implantation in ventricles, or hydrocephalus. The sensitivity is approximately $70 \%$, with specificity ranging from $77 \%$ to $100 \%{ }^{9}$

CSF biochemical examination reveals abnormal results in $88 \%$ of patients, including pleocytosis, increased protein, and low glucose levels. The detection of malignant cells on cytology is essential for diagnosis. However, almost half of the patients with LC have no malignant cells detected on their first LP. This may be explained by the propensity of malignant cells to adhere to the leptomeninges rather than being suspended in CSF. A large amount of CSF should be obtained for analysis since the false-negative rate of CSF cytology decreases from $32 \%$ to $10 \%-3 \%$ as the sample size increases from $3.5 \mathrm{~mL}$ to 7-10.5 mL, respectively. In addition, fast processing and CSF withdrawal from a site of clinical or radiologic disease may further contribute to increased sensitivity. ${ }^{10}$ Indeed, in our patient, lumbar meningeal involvement, not present at the time of the first LP, along with the collection of a higher volume of CSF, likely contributed to detecting malignant cells in the second sample. Hence, the procedure should be repeated if the initial sample is negative and there is a high index of suspicion. ${ }^{10}$

We report a case presenting with isolated bilateral optic neuropathy initially attributed to an inflammatory etiology. Despite the absence of structural abnormalities on contrast-enhanced MRI and the negativity of CSF cytology, the development of areflexic paraparesis strengthened the hypothesis of a diffuse leptomeningeal process leading to repeat LP. The present case highlights the importance of considering LC in the broad differential diagnosis of optic neuropathy, even in the absence of other cranial nerve involvement. Moreover, it emphasizes the utility of repeating an LP and collecting high CSF volume $(\geq 10$ $\mathrm{mL}$ ) to submit for CSF cytology examination if the clinical suspicion of LC persists.

\section{Acknowledgment}

The authors thank Cecilia Baroncini for editing the English text.

\section{Study Funding}

The authors report no targeted funding.

\section{Disclosure}

The authors report no disclosures relevant to the manuscript. Go to Neurology.org/ $\mathrm{N}$ for full disclosures.

\begin{tabular}{|c|c|c|}
\hline Name & Location & Contribution \\
\hline $\begin{array}{l}\text { Simone } \\
\text { Rossi, MD }\end{array}$ & University of Bologna, Italy & $\begin{array}{l}\text { Writing of the manuscript, } \\
\text { guarantor }\end{array}$ \\
\hline $\begin{array}{l}\text { Giulia } \\
\text { Amore, MD }\end{array}$ & $\begin{array}{l}\text { IRCCS Istituto delle Scienze } \\
\text { Neurologiche di Bologna, Italy }\end{array}$ & $\begin{array}{l}\text { Clinical insight, revision of } \\
\text { full text }\end{array}$ \\
\hline $\begin{array}{l}\text { Umberto } \\
\text { Pensato, MD }\end{array}$ & University of Bologna, Italy & $\begin{array}{l}\text { Clinical insight, revision of } \\
\text { full text }\end{array}$ \\
\hline $\begin{array}{l}\text { Roberto } \\
\text { D'Angelo, } \\
\text { MD }\end{array}$ & $\begin{array}{l}\text { IRCCS Istituto delle Scienze } \\
\text { Neurologiche di Bologna, Italy }\end{array}$ & $\begin{array}{l}\text { Clinical insight, revision of } \\
\text { full text }\end{array}$ \\
\hline $\begin{array}{l}\text { Rita Rinaldi, } \\
\text { MD }\end{array}$ & $\begin{array}{l}\text { IRCCS Istituto delle Scienze } \\
\text { Neurologiche di Bologna, Italy }\end{array}$ & $\begin{array}{l}\text { Clinical insight, revision of } \\
\text { full text }\end{array}$ \\
\hline $\begin{array}{l}\text { Maria } \\
\text { Guarino, MD }\end{array}$ & $\begin{array}{l}\text { IRCCS Istituto delle Scienze } \\
\text { Neurologiche di Bologna, Italy }\end{array}$ & $\begin{array}{l}\text { Clinical insight, revision of } \\
\text { full text, lead clinician }\end{array}$ \\
\hline $\begin{array}{l}\text { Pietro } \\
\text { Cortelli, MD, } \\
\text { PhD }\end{array}$ & $\begin{array}{l}\text { IRCCS Istituto delle Scienze } \\
\text { Neurologiche di Bologna, Italy }\end{array}$ & $\begin{array}{l}\text { Clinical insight, revision of } \\
\text { full text, lead clinician }\end{array}$ \\
\hline
\end{tabular}

\section{References}

1. Newman N, Biousse V. Diagnostic approach to vision loss. Continuum. 2014;20(4 Neuro-ophthalmology):785-815. 
2. Biousse V, Newman NJ. Diagnosis and clinical features of common optic neuropathies. Lancet Neurol. 2016;15(13):1355-1367.

3. Hayreh SS, Podhajsky PA, Zimmerman B. Ocular manifestations of giant cell arteritis. Am J Ophthalmol. 1998;125(4):509-520.

4. Vodopivec I, Rizzo JF 3rd. Ophthalmic manifestations of giant cell arteritis. Rheumatology. 2018;57(suppl 2):ii63-ii72.

5. Cross SA, Salomao DR, Parisi JE, et al. Paraneoplastic autoimmune optic neuritis with retinitis defined by CRMP-5-IgG. Ann Neurol. 2003;54(1):38-50.

6. Moloney TP, Xu W, Rallah-Baker K, Oliveira N, Woodward N, Farrah JJ. Toxic optic neuropathy in the setting of docetaxel chemotherapy: a case report. BMC Ophthalmol. 2014;14:18.
7. Wang N, Bertalan MS, Brastianos PK. Leptomeningeal metastasis from systemic cancer: review and update on management. Cancer. 2018;124(1) 21-35.

8. Pan Z, Yang G, He H, et al. Leptomeningeal metastasis from solid tumors: clinical features and its diagnostic implication. Sci Rep. 2018;8(1):10445.

9. Straathof CS, de Bruin HG, Dippel DW, Vecht CJ. The diagnostic accuracy of magnetic resonance imaging and cerebrospinal fluid cytology in leptomeningeal metastasis. J Neurol. 1999;246(9):810-814.

10. Glantz MJ, Cole BF, Glantz LK, et al. Cerebrospinal fluid cytology in patients with cancer: minimizing false-negative results. Cancer. 1998;82(4):733-739. 


\section{Neurology}

Clinical Reasoning: A 79-Year-Old Woman With Subacute Bilateral Visual Loss

Simone Rossi, Giulia Amore, Umberto Pensato, et al.

Neurology 2021;97;e1159-e1165 Published Online before print May 27, 2021

DOI 10.1212/WNL.0000000000012235

This information is current as of May 27, 2021

\section{Updated Information \&} Services

References

Subspecialty Collections

Permissions \& Licensing

Reprints including high resolution figures, can be found at: http://n.neurology.org/content/97/11/e1159.full

This article cites 10 articles, 0 of which you can access for free at: http://n.neurology.org/content/97/11/e1159.full\#ref-list-1

This article, along with others on similar topics, appears in the following collection(s):

Cerebrospinal Fluid

http://n.neurology.org/cgi/collection/cerebrospinal_fluid Cranial neuropathy

http://n.neurology.org/cgi/collection/cranial_neuropathy

Optic nerve

http://n.neurology.org/cgi/collection/optic_nerve

Visual loss

http://n.neurology.org/cgi/collection/visual_loss

Information about reproducing this article in parts (figures,tables) or in its entirety can be found online at:

http://www.neurology.org/about/about_the_journal\#permissions

Information about ordering reprints can be found online:

http://n.neurology.org/subscribers/advertise

Neurology ${ }^{\circledR}$ is the official journal of the American Academy of Neurology. Published continuously since 1951, it is now a weekly with 48 issues per year. Copyright () 2021 American Academy of Neurology. All rights reserved. Print ISSN: 0028-3878. Online ISSN: 1526-632X.

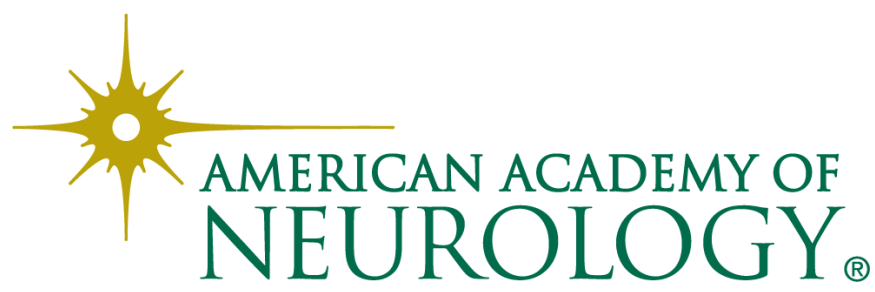

